MISCELLANEA
GEOGRAPHICA

Vol. 13/2008

pp. 239-250

\author{
Karolina Sobczak \\ University of Warsaw - Faculty of Geography and Regional Studies \\ 00-927 Warsaw, Krakowskie Przedmieście 30 \\ e-mail: karolina.sobczak1@gmail.com
}

\title{
CHANGES IN THE ENVIRONMENT \\ AND MIGRATION IN SOUTHERN MOROCCO \\ - EXAMPLE OF THE MHAMID OASIS
}

\begin{abstract}
The subject of the article is an analysis of changes in the environment and economy of oases in southern Morocco, on the basis of a case study of Mhamid. The conclusions are that water investments carried out in the Draa Valley intensified the desertification process. This is exemplified by a stronger aeolian deflation, worsening living conditions of the population, limiting of arable areas and finally, migration. Paradoxically, because of desertification, the region has a chance to develop economically because the newly created sand dunes fields stimulate development of tourism.
\end{abstract}

Key words: Morocco, migrations, desertification, Mhamid, Oued Dra.

\section{INTRODUCTION}

During the process of civilization development and technological progress people learned to cultivate even less fertile areas. However, human interference in the environment often resulted in upsetting the natural balance. An example of this is river-control in desert areas which has contributed to intensification of the desertification process, thus indirectly influencing deterioration of living conditions.

Worsening living conditions in the dry zone intensify migration of people who live there. Migration is usually caused by such economic factors as the need to change the life style. Associated with it is the need to find other income sources. Very often migration stems also 
from changes in the natural environment, for example dune encroachment onto arable fields and buildings, strong soil erosion limiting agricultural activities which due to small crop production and high costs are not cost-effective. Both factor categories, i.e. environmental and economic, are very often strictly interrelated.

However, intensification of the desertification process and development of dune fields connected with it not only exert negative influence on the migration balance. Areas where dunes develop are very attractive for tourism as well as for investors from abroad. The tourism infrastructure - the accommodation and catering industry - is developing in these areas. New investments generate new jobs and new possibilities. Nevertheless, the local population does not always want to take advantage of these opportunities. Often, they are not capable of doing so.

\section{THE AIM AND SCOPE OF RESEARCH}

In the study attention is focused on the southern areas of Morocco - the Coude du Dra Region, exemplified by the Mhamid Oasis in the Oued Dra Valley. On that river, near the town of Ouarzazate, a dam was built and opened in 1971-1972. The dam is one of the two large scale investments carried out southern Morocco.

The first is the Mansour Edaddhbi dam in the Dra Oued, the second is the Hassan Addakhil dam in the Oued Ziz. Both dams were built to ensure stabilization of agricultural production and continuous irrigation of the downstream areas. These areas, however, have not been included in the land development plan, which was to aim at transforming the local agricultural structure. Land consolidation has not been carried out and no change of production technologies or new crop rotation has not been initiated. Thus the irrigation system did not meet the expectation of the community, did not contribute to the fight against hardships of the environment and elimination of overpopulation and excessive utilization of water resources (El Fasskaoui 2005). In the oasis, located in the valley but far from the dam, river periods have become episodic. This resulted in lowering of subsoil waters levels, which subsequently resulted in initiation of the desertification process. The latter can be observed in the reduction of vegetation thickness and often is the beginning of the dune creation process. 
Deterioration of the natural environmental conditions, lack of agricultural development, strongly stratified and hierarchic society, overpopulation, pasture deterioration, excessive utilization of natural resources and lack of state assistance led to the intensification of the process of migration from these areas. However, due to these same factors, this region is attractive for tourism which has led to an influx of tourists as well as people who find jobs in the tourism sector and investors.

\section{RESEARCH METHODS}

Field research was carried out in the examined area on several occasions between March 2005 and December 2007. The following research methods were used:

- individual in-depth interviews with current inhabitants. The questions concerned:

- environmental conditions of the area,

- changes in the natural environment and their influence on the living conditions of the local population,

- development of plant and animal diseases following changes in irrigation,

- change of crop areas and crop size,

- new investments in the oases,

- quantity and quality of water resources,

- methods for limiting desertification,

- tourism development in the area and its influence on the social and economic situation of the oasis.

- participative observation;

- water level and depth of the surveyed wells;

- comparison of the present situation with the situation described in the bibliography (Frankfurt-Nachmias, Nachmias 2001 and Hammersley, Atkinson 2000).

Interviews were carried out with representatives of different social groups. They included those who, thanks to the spreading of the dunes, can operate tourism activities in the area and those whose livelihood and living conditions are dependent on agriculture. 


\section{LOCATION OF THE RESEARCH AREA}

The Mhamid Oasis is situated in the Coude du Dra Region, in southern Morocco, near the border with Algeria. The town of Mhamid with a population of 2000 inhabitants is the biggest in the region. It is situated in a wide, parallel oriented valley in the central part of the Coude du Dra Region. The river bed traverses the centre of the Mhamid oasis.

\section{WATER RESOURCES OF THE OASIS}

Prior to the construction of the reservoirs, the main water source in the oasis in the Oued Dra Valley was water in the river bed and alluvia. The rising of the river water level harmonized with the rain periods and the period of snow thaw in the Atlas Mountains, where the Oued has its sources. Precipitation usually occurred in March and in autumn, from September till December. It differed in intensity and duration. Irregularity of water flow in the river caused difficulties in land cultivation and foremost, in planning irrigation activities (Pletsch 1971). Nowadays, the main source of field irrigation in Mhamid is water delivered by a system of channels and dams from the reservoir south of Ouarzazate and - to a lesser extent - by rainfall. During research conducted in 2005 , local inhabitants said that rainfall lasts about 1 hour and recurs over several consecutive days. In the spring of 2007, in southern Morocco, rainfall was so intensive that for the first time since time immemorial, water in the river bed reached the level of the Mhamid Oasis. The same situation recurred in autumn of that year.

Until the dam south of Ouarzazate was built, Dra Oued was a periodical river up to Mhamid. Nowadays, the Dra Valley, upstream from Mhamid on the $200 \mathrm{~km}$ section, is crossed by 80 dams of different height, which store water for irrigation purposes. The biggest was built in 1972 in Mansour ad Dhabi, south of Ouarzazate (Dłużewski 2003). This dam significantly decreased the water supply in the area downstream. Water in the bed of Oued and in alluvia is dammed at next dams. Their location is strictly connected with the location of the oases. Thanks to the system of water gates, dammed water is delivered to the channels running along the Oued and irrigates the surrounding 
fields. Excess water flows back to the river bed and then to the next dam. It is dammed there once again and directed through a system of channels to the surrounding fields. However, this irrigation system causes water loss. In the open channels there is huge evaporation and water flowing in alluvia soaks into the deeper layers.

Water delivered from the storage reservoir is not the only source of supply of the oasis. Three wells located $21 \mathrm{~km}$ north of the oasis at the foot of Jebel Bani are an additional water source in Mhamid. Fresh water is directed through the pipeline to the town and people can take it from few water intakes located in different areas of the oasis. Tourists have it in abundance as the water is delivered directly to the hotels.

In other parts of Morocco the foggar system is used as an additional water source. It consists of digging channels which incise the water-bearing layer. Formerly, construction of such systems was very risky. Works were carried out underground and often workers were buried. This is the reason why these works were carried out by slaves (Plit 1999). Nowadays, a deep channel is dug until the water-bearing layer is incised, then the channels are covered by stone plates and filled up. This to prevent water from evaporating and from filling up the channels by encroaching dune forms. Barczuk and others (2005) indicate that the idea of construction of such channels is debatable. Undoubtedly, they supply water to the oases. This allows people to work in agriculture, at least for their own benefit. On the other hand, if sources other than alluvial are used, it results in exploiting nonrenewable resources. This generates the risk of exhausting them.

\section{AEOLIAN FORMS IN THE OASIS AND FACTORS FORMING THEM}

Almost the whole Coude du Dra Region is covered by different Aeolian forms. Mainly, they are barchans, barchan-like dunes and fields of blown-sand. The highest forms reach $111 \mathrm{~m}$ (Pletsch 1971, Dłużewski 2003). For the Mhamid Oasis important are three areas of dune fields, whose height does not exceed $6 \mathrm{~m}$. The first is on the western edges of the oasis. They are mainly traverse dunes and single small barchans. Some of them are halted on obstacles, mainly palm trees, and start to create compound barchan forms. Interdune corridors are lower. On the arable fields, accumulation of sand on the palm 
trees, which do not fruit any more, is a form of anti-dune protection. The rate of dune movement is not high and it additionally decreases when the dune is closer to the oasis. Dunes halted on palm trees move even more slowly and in fact, only their arms move. Palm trees give testimony to the fact that the area was arable. Now only tamarisks can be observed rarely, which indicates a high level of soil salinity. Thus, the area was left because of soil salinity and not because of dune development.

The second dune area borders on the oasis from the south. There fields on the loamy ground were formerly arable as there are remains of hardened embankments of small water distributing channels. Among the Aeolian forms, predominant are young barchans and initial transverse dunes. There are also higher forms which accumulate sediment on the dune fencing and tree trunks. Young forms of dunes show that the area was deserted not long ago. According to the local population, 15 years ago the fields were arable and cultivated and there was no Aeolian process. Similar dune forms occur also along the road linking Mhamid and Oualad Driss but only along sections where the road is perpendicular to the direction of the wind gust.

The third dune area is in the Oued bed. Since the dam was built, water in the bed appears very rarely. This has caused drying of the material and intensification of the deflation process. Material is accumulated in the initial and young form of barchans and small nebka dunes, which were created thanks to the vegetation on the bottom of the river bed. From the main bed, material is foremost transported to the northern part of the town. There even are some deserted buildings filled with sand up to the top of the walls.

\section{THE SOCIETY OF THE OASIS}

The society in the oases of southern Morocco is not homogenous. It was formed under the influence of nomadic people, slavery and local inhabitants of the area. The first settlements took place in the XIVth century and the population was of Jewish descent. Descendants of this group lived in Mhamid until the 50's of the XXth century and their dialect is still to be observed in Zenaga - the south-eastern part of Mhamid. Arabs and slaves then came to Mhamid. A caste system, in which Arabs were the most privileged group, was initiated. 
People living in the Dra Valley are Draoui. Their name is derived from the name of the valley. This is not the only meaning of this word. For Mhamid citizens, Draoui are the descendants of black slaves who in the 30's of the XX century gained freedom (Plit 1999). Seemingly, 80 years after the collapse of slavery, differences between groups are fading. In fact, however, divisions still continue to be present. Marriages are entered into inside tribes and each group is dedicated to activities carried out by their ancestors. Draoui is the main group engaged in agriculture. After the flow of water in Dra was limited, their living conditions worsened. Parasites destroying palms, more and more limited access to water and subsequent decrease of arable land forced them to look for new income sources. They left for other towns or oases where they looked for work in, among others, in trade and agriculture. Nomadic people of Arabic descent rate among the Aarib tribe. Formerly, this group occupied itself with trans-Saharan transport and herding. Nowadays, when most of the nomads settled in oases, they started to deal with tourism and run the so called "camps" and are engaged in hotel management. Some of them are employed in trade, mainly in the tourism sector (Photo 1).

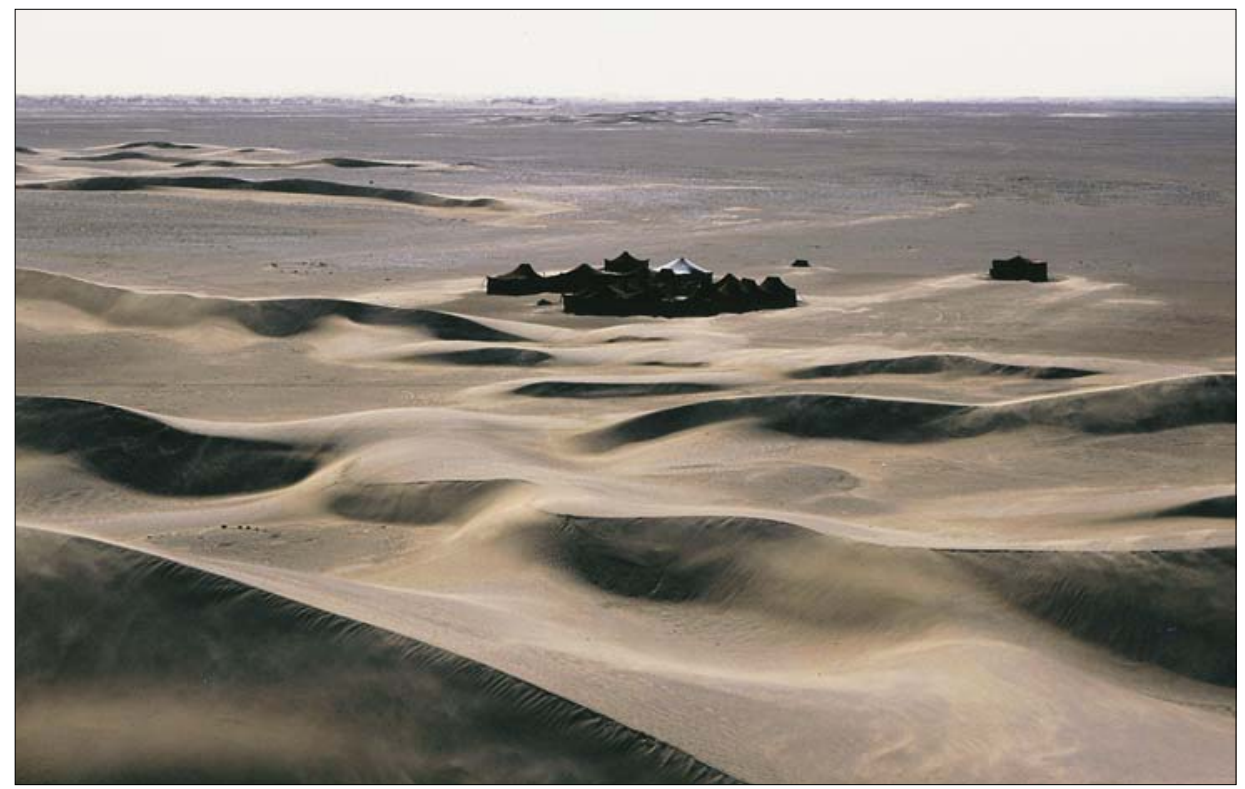

Photo 1. Camp on northern dunes 


\section{THE ECONOMY}

People living in oases derive their income from a few sources. Their activities depend on the conditions and resources to be found in the area. In the case of Mhamid, it is agriculture, farming and tourism.

The main crop in the oases is the date palm. There are currently three times less palms in Mhamid than in other oases of the Dra Valley. However, during research conducted in March 2005, people complained about a parasite which had mainly attacked leaf shoots. Sick palms may be seen in the oases of all of southern Morocco. According to the information gained during interviews in Mhamid in March 2005, before the plague one could have $20 \mathrm{~kg}$ of dates from one palm. Since the draught and parasite attack, palms in the Mhamid oasis almost do not fruit. People try to fight against the parasite and set fire to sick palms. That is why many tree stumps can be seen as evidence of former plantations. Fortunately, most of the palms regrow and fruit again (Photo 2).

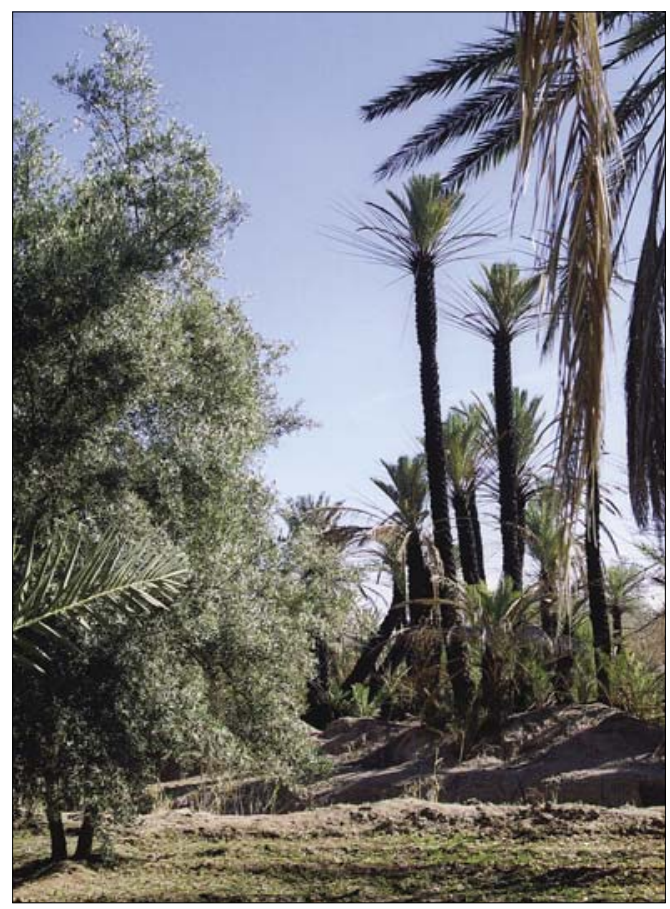

Photo 2. Palms which regrew after a fire was set against parasites 
Among the species grown in the oases of southern Morocco there are mainly animals tolerant of hard conditions of the hot and dry climate. However, worsening of living conditions has also influenced animal breeding. In the 80's of the XXth century, among livestock in Mhamid, sheep bred for meat were predominant (over $60 \%$ of the stock). At the time, among draught animals, the most important were donkeys and mules. In the 80's, two hundred nomads lived in Mhamid. They occupied 170 tents, were owners of 30 palm groves and few camel stocks. During the next years, after mechanized transportation became widespread, they were forced to retrain from camel breeding to easier and cheaper breeding of sheep and goats. However, the plague that spread through the Dra Valley, associated with desiccation of the Iriqui Lake, put an end to camel breeding (Establissement d'un plan... 1981; Dłużewska 2003).

Currently, in the oases, tourism is becoming more and more important. Although the first tourist investments in Mhamid took place in the 30's of the XXth century (Sahara Hotel), intensive development started only 12 years ago. Those inhabitants who did not relocate to other places with their animals currently are engaged in tourism. As a result of tourism development camels were brought back here because they and growing dunes are the main tourist attractions.

Profits from tourism development are important also for people who are not directly associated with this sector of the economy. Tourists walking in the oases are very often invited to houses where they are offered tea and home baked bread and then are asked for la small gratuity.

Foreign entrepreneurs are the main investors contributing to the development of tourism in Mhamid. Investors from the Netherlands, Portugal, Spain, France or Norway invest their money in hotels in the oasis but are not themselves present there. They cooperate with educated Moroccans, landowners who are responsible for business. Investing in tourism seems to be profitable because two or even three new hotels are built each year. Both inhabitants and people who come from other places are employed in the tourism service sector. They must meet employer requirements, i.e. must speak a foreign language. They are occupied in hotel services and take tourists to interesting places. It is important that a person guiding a caravan into the desert knows the area. That is why, according to workers, mainly people who grew up in this area do this job. For Mhamid, tourism is a chance 
for development but members of the local population who could have found work in this sector have, for the most part, departed. According to the inhabitants, young people are divided in three groups. Half of them is in the army and left for military units located in other parts of the country. Many young people work in tourism but in order to find customers they left for towns like Zagora, Ouarzazate and Marrakech. There is also a group of people, mentioned rarely, who went abroad to find work. Often, they were able to obtain a visa thanks to a marriage with a European. In consequence of emigration, often people who work here come from other towns, some even a few hundred kilometres away from Mhamid.

\section{CONCLUSIONS}

Prior to the construction of the dam south of Ouarzazate, inhabitants of Mhamid worked in agriculture. Regular high waters in Dra Oued which often reached the crops allowed them to make a living by working in agriculture in the Mhamid oasis area. The dam significantly influenced changes in the living conditions of people living downstream of the construction. Periodically, water in the bed reached Zagora. However, water flowed to Mhamid mainly through channels. Thus the desertification process is most visible there. Lowering of the subsoil waters resulted in a high level of soil salinity and started the desertification process. Dunes encroached on the oasis both from the surrounding areas and from the dry bed of Dra, which traverses the centre of the oasis. Dunes encroached not only on fields but also on houses forcing people to move away. Newly built channels which were to distribute water to the fields located a few kilometres away from the oasis, gave some hope to the inhabitants for future crops. However, water was flowing there only on the day of the channel inauguration and never again.

Ploughed and dry field soil prepared for sowing is very easily blown away which results in increasing the intensiveness of the deflation process. Such a situation doesn't offer bright perspectives. Young people left Mhamid to study, to find work in other towns and they seldom come back home. Very often, only older people and children remained home. They make ends meet thanks to the help of people who left or by generating new sources of income. Members of the local com- 
munity admit that in a few year, none of the former inhabitants will remain here. It must be stressed that emigration is not only caused by changes in the natural environment. In addition, the situation is also influenced by numerous economic factors. Those who leave do not want to live in houses with a dirt floor. They want to study and find work in the city and in consequence, to improve their economic situation. On the other hand, people who arrive in Mhamid are able to perceive a perspective for tourism development. Foreign entrepreneurs invest in new hotels and in digging wells which supply water to hotels.

A fact deserving special attention is that, regardless of the reason for it, migration is a two-way process. Some people leave because they want to change their life. Others arrive because, due to numerous environmental changes, they see future business opportunities in Mhamid.

\section{REFERENCES}

Barczuk A., Dłużewski M., Dubis L., Skocki K., 2005, Rozwój pól wydmowych Ergu Chebbi, [Development of dunes areas of Erg Chebbi; in Polish] [in:] Dłużewski M., Tsermegas I. (eds.), Warsztaty geomorfologiczne Maroko [Geomorphologic field workshop in Morocco] 19.04-04.05.2006, Wydział Geografii i Studiów Regionalnych, Uniwersytet Warszawski, Stowarzyszenie Geomorfologów Polskich, Warszawa.

Dłużewska A., 2003, Wplyw środowiska przyrodniczego na warunki życia ludności autochtonicznej, Wspótczesna ewolucja środowiska przyrodniczego regionu Coude du Dra (Maroko) i jej wptyw na warunki życia ludności, [in:] Dłużewski M. (ed.) Wspótczesna ewolucja środowiska przyrodniczego regionu Coude du Dra (Maroko) $i$ jej wptyw na warunki życia ludności [Influence of the environment on the living conditions of population, Contemporary evolution of the environment of the Coude du Dra Region (Morocco) and its influence on the living conditions of the population; in Polish], Wydawnictwo Akademickie Dialog, Warszawa.

Dłużewski M. (ed.), 2003, Wspótczesna ewolucja środowiska przyrodniczego regionu Coude du Dra (Maroko) i jej wptyw na warunki życia ludności, [Contemporary evolution of the natural environment of the Coude du Dra Region (Morocco) and its influence on the living conditions of the population; in Polish], Wydawnictwo Akademickie Dialog, Warszawa.

El Fasskaoui Brahim, 2005, Południowo wschodnie obszary Maroka: formy i organizacja życia na pustyni, [South-eastern areas of Morocco: form and organisation of life in the desert; in Polish] [in:] Warsztaty geomorfologiczne Moroko (Geomorphologic field workshop in Morocco) 19.04-04.05.2006, Dłużewski M., Tsermegas I. (eds.), Wydział Geografii i Studiów Regionalnych, Uniwersytet Warszawski, Stowarzyszenie Geomorfologów Polskich, Warszawa. 
Etablissement d'un plan directeur de mise en valeur agricole de la vallée du Drâa moyen, 1981, Ministère de l'Agriculture et de la Réforme Agraire, Maroc Développement, Rabat.

Frankfurt-Nachmias Ch., Nachmias D., 2001, Metody badawcze $w$ naukach społecznych, [Research methods in social sciences; in Polish], Zysk i S-ka Wydawnictwo, Poznań.

Hammersley M., Atkinson P., 2000, Metody badan terenowych [Methods of field research; in Polish], Zysk i S-ka Wydawnictwo, Poznań.

Pletsch A., 1971, Strukturwandlungen in der Oase Dra, Marburg, Lahn.

Plit F., 1999, Wyludnianie się Sahary i Syberii [Depopulation of Sahara and Siberia; in Polish], Prace i Studia Geograficzne, tom 25, Warszawa.

English translation: Jakub Fulara 